\title{
Industrial Policy: Promising Possibilities for African Economic Growth and Development
}

\author{
Majeed A. Rahman \\ University of Wisconsin-Milwaukee
}

\begin{abstract}
The main body of this paper is made up of two separate parts each engaging and examining different aspects of industrial policy as they are related to developing African economies. The first part examines the importance of geography and contextual relevance in designing a developmental industrial policy. This part explores how different African economies may each configure their respective industrial policies in relation to their own geography and, social, cultural, and economic context so as to achieve success. The second part explores the important role the state plays in enacting and configuring an effective developmental industrial policy. This part especially highlights how the most effective industrial policy in terms of enhancing multi-sector economic growth tends to be policies enacted by developmental States that are highly involved in implementing specialized and highly integrated developmental policies that consolidate linkages across economic sectors, and is fully embedded into a broader economic development plan.
\end{abstract}

\section{INTRODUCTION}

The importance of industrialization in boosting economic growth and development in Africa cannot be overemphasized. Indeed, Africa's initial attempt at industrialization policies began in the 1950s and 60s, which apparently was halted in the late 1980s as a result of Africa's pursuit of the Washington consensus policies that shifted economic policies and structural development from state-led development economy to a more liberal neoclassical model that focused on trade liberalization and free market enterprise. Neoliberal policies in Africa led to

Social Evolution \& History, Vol. 17 No. 1, March 2018 108-122

(C) 2018 'Uchitel' Publishing House

DOI: $10.30884 / \mathrm{seh} / 2018.01 .06$ 
several questions and assumptions as to their implementation. It is pertinent therefore, at this juncture to share with you some of the questions raised by Oyeyinka and Sampath when they ask: why is technology transfer not an adequate precondition for technology absorption? And why is public sector research ineffective in promoting product development through the private sector? (Oyeyinka and Sampath 2012). While we may not seek to answer these questions here, intuitively a glimpse of the answers will throw more light in the direction of this paper. Consequently, this paper examines both the interventionist role of the state in pursuing an industrial policy through a developmental state paradigm and the mode and process through which developing countries can aim at developing the framework of action that boost industrial policy in Africa. This paper is divided into two sections. The first section talks about the realities of industrialization in selected African countries and the significance of industrial policy in rolling less developed countries to catch up with more industrialized states. While the second part looks at the role of the developmental state in diversifying latecomer countries' economies in their pursuit towards convergence.

\section{INDUSTRIAL POLICY IN DEVELOPING COUNTRIES}

Sub-Saharan African countries need to industrialize in order to pursue an optimal development. It is for this reason that appropriate industrial policies have to be implemented and applied to obtain sustained economic growth, which will lead to the catch up process and convergence with developed countries. Africa's lessons learnt together with inspiration from the successful experiences of East Asian countries and Ireland's industrial policies will undoubtedly increase productivity, competence, improve the standard of living of the population, accelerate poverty reduction, favor technology transfer, and more importantly increase the GDP per capita of all Sub-Saharan African countries. No doubt, it is pertinent to recognize that the Asian industrial policy experience has been successful and therefore worth emulating by latecomer countries. As Robert Wade (2012: 258) puts it 'A country's rate of growth is much affected by its production structure'.

This section suggests a national plan composed of a set of actions for some African landlocked countries' industrial development (Rwanda, Mali or Central African Republic) through free industrial zones, export processing zones, parks, foreign direct investment (FDI), accumulation of capital, rent creation, capture of externalities and spillovers, linkages, technology transfer, human or knowledge capital building, 
and international trade will take place. In this paper, I also examine the possibility and necessity for each African country to create a national plan to develop activities in industrial sector with the main objective of producing high value added manufactured goods and services. This is the only efficient way for Sub-Saharan African countries to prosper and become cable to integrate the global market and benefit international trade. As we know, East Asian countries, particularly South Korea, Malaysia, Thailand, Indonesia, Singapore and notably China, to name just a few, greatly succeeded in industrial policies formulation. What is especially interesting with respect to these two regions is that East Asian and Sub-Saharan African countries share some common features like diversity and factor endowment. Indeed, similar to the East Asian region Africa is diverse and there are countries both resource-rich and resource-poor as well as landlocked rich and poor countries. Matsuo Watanabe and Atsushi Hanatani (2012: 382) show that 'Although Asia's development is commonly characterized as export-oriented industrialization, the development paths have been diverse among the region in practice; individual economies pursued different development strategies according to their different endowments and circumstances'.

\section{THE MEANING OF INDUSTRIAL POLICY}

From the outset, Akbar Norman and Joseph Stiglitz (2012) propose an excellent definition that fits perfectly the purpose of this paper in regard to what we try to achieve here. They argue,

There are many dimensions to what is called 'industrial policy' and it has taken markedly different forms in different countries. Learning, industrial, and technology policies (LIT) focus on learning, especially by infant industries and economies, they focus on externalities and knowledge spillovers, they typically (especially in Asia) consist of promoting exports and the private sector. They apply not only to manufacturing, but also to other sectors, such as agriculture, and to modern services, such as information technology or Finance (Norman and Stiglitz 2012: 24).

It should be noted that not every industrial policy is good for different countries. The literature shows the evidence of abundant examples of failed industrial policy. The African countries should pay special at- 
tention and learn from past experiences to avoid failures in the future. We know that economic history is full of industrial policy failures.

The main question here becomes how industrial policy should be designed and implemented more effectively in African countries. In this regard, Izumi Ohno and Kenichi Ohno also explain

Not all feasible policies are desirable and not all desirable policies are feasible. To be effective, a policymaker at any level or in any organization must track his or her brains for a narrow and delicate set of actions that satisfy both feasibility and desirability. Because all countries are different in both aspects, no one-size-fits-all solution can apply (Ohno I. and Ohno K. 2012: 225).

The ultimate goal of industrial policy in African countries should not only focus on promoting structural change, finding new business models and markets, but also on creating new products and activities (Altenburg 2011).

\section{THEORETICAL MODEL}

This paper assumes that developmental state model that entails significant government intervention in the conduct of the market is conducive for setting development agenda. That is creating and stimulating the private sector to expand industrialization.

Industrial policy is related to state or government intervention, which is the only agent that can create policy, market does not have agenda or incentives to be involved implementing policies. The government is directly responsible for designing and implementing development policies in developing countries. First of all, every country in Africa needs and should build a developmental state in order to succeed in formulating great industrial policies to avoid market failures by providing public goods and building major social and economic infrastructures, so that market can perform well. The state has the mission to help capturing externalities and spillovers, favor linkages, and stimulate rent creation to accelerate economic growth. Sub-Saharan African countries do not stand any chance to succeed in industrial policy formulation without at first building a developmental state; market will never create policies for them. The fundamental role of development state must be to change radically the mode of production and create opportunities for everyone in the country to live well, be happy and prosperous. 
It has been said that the majority of African countries achieved great economic performances, but this economic growth is only due to the boom of commodities selling. What Africa wants now is to sustain this economic growth by industrialization of the whole continent and to start massive production of manufactured goods and provide great services as developed countries do. Africa must henceforth avoid selling its raw materials without first processing them. In other words, we need to make commitment to add value to our commodities before selling them. I truly understand that developmental state will have the power and responsibility to make effective industrial policy.

For Meles Zenawi (2012), the mission of a developmental state is to accelerate development. He argues that 'the developmental state ought to be autonomous from the private sector' (Zenawi 2012: 168). State autonomy is one characteristic that distinguishes the developmental state from others. Government must provide guidance to economy. At the same time, Meles Zenawi identifies two fundamental characteristics - autonomy and hegemony - which constitute the basis of the developmental state. He highlights the role of autonomy in industrial policy formulation. He affirms that

First, the autonomy of the developmental state is reflected and described by its ability to make effectively implement policies regardless of the views of the private sector on the issue. And second, it tries to guide the private sector to make its decisions in a manner that accelerates growth by using asset of incentives and disincentives (Ibid.: 168).

Without mastering this important concept autonomy in African countries, it will be very difficult to achieve industrial policy success.

It is important to mention that this topic is very broad and needs much time and many researches to cover it entirely. It is almost impossible to study this important problem just within the scope of this paper. Thus, here we will focus mainly on what types of industrial policy should be created in landlocked countries in Sub-Saharan Africa such as Rwanda, Mali or Central African Republic to help them achieve economic development; what is under industrial policies and what points can be considered to be the factors of a successful industrial policy. In order to make effective industrial policy, each country is required to put in place an appropriate national innovation system in conformity to the context, location and situation. The context, specificity and potentiality of each really matter. There should be variations 
among resource-rich, resource poor and landlocked countries in SubSaharan Africa when it comes to decisions or actions to take.

It should absolutely be evident and clear in our mind that to design or create efficient, industrial policies in developing countries, physical geography should always be taken into account due to its relevance and since it constitutes an important determinant of economic growth. Among these numerous and different types of industrial policy, which ones will fit better for these chosen landlocked African countries? It is well known that the most used and applied industrial policies in East Asian countries were the creation of economic processing zones, export processing zones, special economic zones, and rent creation, which consisted of endogenizing rent-seeking clusters to capture externalities, public goods and building infrastructures, and a sort of national innovation system following the models of the USA and Germany or in between these two approaches in order to continuously improve technology and increase productivity.

In this regard, in all African countries Deng Xiaoping's method should be applied which consists in trying everything and learning from mistakes. As Izumi Ohno and Kenichi Ohno put it, 'The greatest engine of the Chinese economy that Deng introduced was the attraction of FDI into special economic zones and economic development zones along the eastern and southern coasts' (Ohno I. and Ohno K. 2012: 232). In fact, Africa has nothing to lose by trying this since there exist different types of economic zones, and we observe the effectiveness of these zones in the East Asian countries, notably in China and South Korea. If something does not work, we must stop and change, and try new ways or start new projects. It is important to observe here as Stein and Howard pointed out that 'Disagreements often exists because case studies focus on different zones, some of which have been failures for reasons that include poor location, inadequate infrastructure, and gross mismanagement' (Zenawi 2012: 161). As we know, economic zones have attracted a large amount of foreign investment in East Asian countries. And landlocked African countries should create conditions and incentives to attract abundant foreign direct investment (FDI).

To achieve this goal, landlocked African countries must a implement and experiment all these various types of zones and parks and start building the knowledge capital, which is a very important factor that will help these countries in the process of convergence and catchup their per capita income with other developed nations. They should 
also create many small and medium enterprises (SMEs) in the sectors in which they can have comparative advantage, potential, or predict to obtain a certain competitive advantage in the future. Zenawi underlines that 'A firm masters the technology if it is continuously trying to improve productivity and quality of products' (Zenawi 2012: 161). The landlocked African countries have to continue looking for better strategies and techniques for innovating and creating new products. There are still many things to discover, so that the field remains wide open and infinite to all countries. The most important thing is to take concrete actions in order to sustain economic growth.

\section{EXAMPLES OF INDUSTRIAL POLICY IN SOME \\ LANDLOCKED AFRICAN COUNTRIES \\ (SUCH AS RWANDA, MALI OR CENTRAL AFRICAN REPUBLIC)}

As we know Rwanda, Mali, and Central African Republic are three landlocked African countries, which represent different levels of competitiveness and government effectiveness as well. While the three countries share many characteristics, there are also important differences. To understand what similarities and differences these three countries have, it is useful to look at their geographical configuration and factor endowments. Rwanda is a small country located in Eastern part of Africa bounded by Uganda, Democratic Republic of Congo, Burundi, and Tanzania. Rwanda is the most densely populated country in Africa, and its small size and landlocked nature present barriers to economic growth. Mali and Central African Republic are much bigger than Rwanda and present great differences. It is well known that most part of Mali is covered by the Sahara desert. We can add also that Mali used to be one of the biggest producers of gold in the world. The country still has the potential to repeat what it achieved some century ago. And finally, the Central African Republic covers larger portion of African tropical forest, which provide this country with abundant arable land and offer excellent conditions for agriculture. At some point Central African Republic has produced diamonds.

The former Prime Minister of Ethiopia, Meles Zenawi made a strong argument by affirming that 'the key issue in development is the economic issue of improving agricultural productivity and directing the surplus generated as a result of industrialization' (Zenawi 2012: 166). It is evident for Rwanda, Mali, and Central African Republic which possess enormous potential in agriculture sector to be fully en- 
gaged to develop and transform it. Indeed, as formulated by Izumi Ohno and Kenichi Ohno, 'unique potential for each country should be identified, and the main policy effort must be directed to removing barriers to attain that potential' (Ohno I. and Ohno K. 2012: 230). The real potential for Rwanda reside in the agriculture especially in the production of milk, tea, vegetables such as potatoes and beans, livestock, cattle, cows, energy (can exploit gas under Lake Kivu), tourism and creation of new product in the domain of informatics, telecommunications, information, and chemistry. With the support of economic zones and consistent efforts, Rwanda can succeed to build a strong food industry. The government must take measures to support the development of the agriculture in Rwanda. Banji O Oyeyinka and Padmashree Gehl Sampath (2012: 295) allude to the fact that 'States need to formulate a long-term vision or goal and pursue it. This is perhaps the clearest message that other latecomer countries can derive from the East Asian success stories'. They also explain 'At the initial stage, policy targets mainly focused on creating basic conditions and environment, including locating technology sources both from domestic $\mathrm{R} \& \mathrm{D}$ efforts and commercialization as well as facilitating international technology transfer' (Ibid.: 294).

It should be the same for Mali, which regularly produces massive amounts of cotton and disposes huge land areas of Sahara desert where multiple renewable energy projects can be launched. Mali presents a great potential to be involved in agriculture sector. Indeed, Mali can seriously start thinking about developing textiles and cosmetics industries with cotton and shea tree which is very appreciated and demanded around the world. Something is fascinating about this tree; it grows only in the Sahel area. Mali will also plan on launching a new version of Desertec Project in the Sahara desert. As a reminder, Desertec is a project conceived and financed by Europeans for the purpose of producing solar energy from the Sahara desert. With the new technology, the longtime presumed dead land seems to be an abundant and infinite source of renewable energy. Mali should not miss this excellent opportunity to explore this new way of producing electricity and building capacities to sell the leftover to the neighboring countries. Finally, Izumi Ohno and Kenichi Ohno (2012: 224) emphasize that 'Most latecomers have specialized in labor intensive manufacturing industries such as electronics, garments, footwear, and food processing- and other high-value services'. 
The time has come to define priorities in terms of types of actions to be taken. Solow Model suggested that labor and capital contribute only 50 per cent of the production, while another important part is completed by technology or the total factor of productivity. This is why the Sub-Saharan African countries should develop and strengthen their industrial sector in order to compete with the rest of the world. Zenawi (2012: 152) argues that 'Trained labor is central to technological change and development'. As we know, nothing is impossible in life, the best thing to do is to try. Mali can perform well like Japan did it to the United Kingdom when the former overturned the latter in cotton production. Izumi Ohno and Kenichi Ohno (2012: 232) mentioned 'by the early twentieth century, Japan overtook the United Kingdom to become the top textile exporter in the world and the city of Osaka, where many textile miles were located, was called the Manchester of the Orient'. Mali really possesses the potential to develop textiles industry.

The three countries can be successful in producing food and creating strong agro-industry. Food is an important commodity that every country needs to survive. This sector must be a priority for these countries in order to satisfy basic needs of the population, especially food. The government should give more incentives to private sector to invest in this sector, by endogenizing rent-seeking, subsidies, creating clusters to capture externalities and spillovers, and attract more FDI and other foreign investors. For instance, with respect to Thailand, Izumi Ohno and Kenichi Ohno observe that 'The Thaksin government wanted to promote industries that had domestic value-added and created many jobs regardless of the nationality of the firm. Targeted industries included automobiles, agro-industry, fashion goods, high value services, electronics and ITC, energy and renewable energy' (Ohno I. and Ohno K. 2012: 234) They also clearly recommend to 'identify the future potential dynamic comparative advantage unique in each country. Once an area of future potential is identified, resources are poured into this area to realize that potential' (Ibid.: 228). As a matter of fact, agriculture, tourism, energy, IT industry, cosmetics, textiles, agro-industry could become the most dynamic manufacturing sectors in Rwanda, Mali and Central African Republic. These countries should learn especially from China and create as many economic zones as they can to fully enjoy the benefits of this powerful economic system. 
Robert Wade highlights Moran's argument, which is very essential in showing the importance of foreign direct investment (FDI) for African countries in the process of convergence and catch up with rich countries.

Moran argues that in most sectors the only sensible strategy for developing countries is to attract in export-oriented FDI as the prime channel for technological learning: 'foreign investors not only introduce new activities into the host economy but also continuously upgrade the technologies, management techniques, and quality control procedures of their affiliates to keep their sourcing network at the competitive frontier in the international industry' (Wade 2012: 260).

Education is very critical in order to industrialize African countries. The above-mentioned three countries should invest heavily in education and training of their population as well as encourage the development of R\&D sphere and fulfill the key aspect of endogenous growth model in the production process. More agro-engineers and scientists as well as farmers should be trained. It would be good also if these countries give special attention to the training of engineers in the key sectors of water supply and electricity. Nobody can deny that the development of Africa depends on these two spheres.

Sub-Saharan African countries must not be afraid of international trade. Moreover, the industrial policy should help them to transform their mode of production in order to enter and compete in the global market. Therefore, industrial policy should complement the development of international trade. Sub-Saharan African countries need both components to prosper and converge with developed countries. Industrial policy for African landlocked African countries should remain simple, and need not to be sophisticated. It is clear that countries improve industrial policies through the powerful tool of learning by doing.

\section{INDUSTRIAL POLICY AND THE ROLE OF THE DEVELOPMENTAL STATE IN AFRICA}

It is important to conceptually clear the differences between the terms often used in designing and restructuring an economy of the state. Indeed, the terms industrial policy and industrialization are often used interchangeably and almost invariably refer to the same thing. In this paper we argue that the terms industrial policy and industrialization are two separate words meaning two different things. While industrial- 
ization is the movement of an economy from agrarian type to a more integrated and structured economy, industrial policy refers to the set of guides and framework of action that are set out to roll the agrarian economy to the industrialized economy. In this case, industrial policy is the consequence of industrialization (not the other way round). Yet, one cannot occur without the other. Indeed, the two are intertwined to a large degree, but refer to different concepts in their structural processes.

The pervasive nature of market failures and a wide spread of negative externalities that are characterized by the adoption of the orthodox model of economic development in sub-Saharan African countries has been blamed by development experts on Africa's poor institutions and lack of specific policy directive that is capable of realizing the goals and aspirations of the Washington consensus. Indeed, postWashington development and economic restructuring in Africa has been assessed and the postmortem recommendations have concluded that Africa's poor economic performance is the result of poor governance strategies, rent seeking behaviors and corruption. However, a historical reflection of industrialized countries today indicates a significant shift from most of Washington consensus prescriptions in their early stages of industrialization (Zalk 2012). In particular, Britain and the United States have protected their infant industries through several protectionist measures aimed at safeguarding their small and medium industries. Subsidies through tax exemption procedures are among the ways in which most of these industrialized countries embarked on to writ their small firms from competition.

It is against this background, that development and political economists have begun to rethink whether the industrial policies without interventionist role can bring about economic development in latecomer countries, especially in the context of sub-Saharan Africa. It is on this basis that the proponents of industrial policy argue that the state's role is crucial in the allocation of resources, especially in preventing market failures and mitigating the negative and adverse externalities for the state, thereby creating conditions necessary for efficient development.

Neoclassical views on market fundamentalism have often stressed on the need to diversify industrial technology through private participation of firms and corporate institutions. This notion, according to the neoclassical views, is supposed to be diffusing technology acquisition by improving efficiency. By this efficiency argument, the firms freely participating in the market are assumed to provide the technology necessary for industrial take off. This argument cannot indeed be 
stressed much. The mediocre performance of industrial technology in sub-Saharan African countries with the exceptions of South Africa cannot be underestimated (Zalk 2012). South Africa, in the past decades was among the sub-Saharan African countries that had impetus for building industrial technology given its capital base as compared to other sub-Saharan African states.

It is on this basis that Stein argues that industrial policy implies series of interventions aimed at transforming and accelerating economic structures of an industry in order to promote 'development competiveness' (Stein 2012: 328). In this regard the state's role is to provide this competitive edge for local and small manufacturing firms in the face of international competitive markets.

In his article Meles Zenawi, when expounding the state's role in the accumulation of technological capabilities, reiterates the inherent market failures when he alludes that neoclassical economists themselves have come to realize that it is only the state that can organize and implement patents, property rights protection, as well as research and development, because the market fails to allocate resources for the sector's specific development (Zenawi 2012). Furthermore, the increasing return to technological development can be achieved in the state when the government makes it possible for inventors and innovators to invent and create new products for the market. In this case, the state has the responsibility of creating the knowledge base necessary for industrial technology to develop, especially in the context of less developing countries. It is against this background that Zenawi argues that the larger is pre-existing knowledge in the society, the more chances there are that inventions and technological innovations will develop; otherwise a country risks falling in the low technological development trap being incapable of developing its industrial policy (Zenawi 2012).

Since the industrial policies can capture externalities in the context of clustering businesses and firms, the state gets an opportunity to take advantage of clustering and to create technological parks in places where local inputs and outputs can be facilitated and possibly outsourced. However, while the neoliberal system fails to capture these externalities, the interventionist policies possess the trends of rescuing latecomer economies by rolling their less developed economies into the industrial economy.

As a result, Africa needs interventions in the form of industrial strategies supported by the governments in order to spur industrial development. In its report 'Economic Development in Africa 2012' 
the UN Industrial Development Organization emphasized among other things that Africa industrial policies must adhere to the hard learned principles of industrial development necessary for spurring industrial development (UNIDO/ UNCTAD 2012).

Among the core principles, the UNCTAD/UNIDO insists on the support and challenge of entrepreneurs. This is significant for industrial development since the government's intervention in supporting private firms to stimulate investment and other business activities is necessary for both long-term and short-term job creations. The support of private firms should continue until they reach the stage when they become able to stand the market competition in the global market.

This point is also consistent with the article by Izumi Ohno and Kenichi Ohnu 'Dynamic Capacity Development: What Africa can Learn from Industrial Policy Formulation in East Asia'. The East Asian Tigers Experience is significant in general and in particular with respect to special economic zones in China, which are capable of boosting economic growth and development through developing several specific branches of economy involving the employment generation. Stein argues that China's economic zones for instance, employed an estimated 40 million Chinese compared to fewer than 35,000 in South Africa, and completely zero in other sub-Saharan African states (Stein 2012).

The establishment of effective State Business Relations (SBR) is crucial for Africa's industrial development to succeed. Industrial policy is not a one-sided phenomenon. It involves both the public and private sectors in bringing about the cost effective ways of running business while at the same time creating opportunities for entrepreneurs to run a business. An adequate consultation between government and private entrepreneurs in devising the ways to expand the manufacturing base is necessary for industrial development. The confidence reposed by the government in making raw materials available as well as other economic inputs for manufacturing is an essential ingredient that can be facilitated by an effective state-business relation (Sen and Willem te Velde 2012).

The state's ability to eliminate barriers to industrial development by means of its consultations with stakeholders including domestic and private firms is a significant step forward in Africa's industrial take off. In the 1980s and 1990s, the Washington Consensus policies as well as its subsidiary institutions such as the Exim bank and the international financial institutions sought to liberalize African economies through implementation of free trade policies which aimed at lifting barriers for trade through its quantitative zoning policies that re- 
grettably worked to further retard Africa's and slowed the pace of industrial development. As more and more investment is necessary for economic growth, some local and domestic firms in Africa and subSaharan Africa were totally extinguished while others fell at the mercy of foreign companies. With the hard lesson learnt today, Africa's industrial trajectory can be achieved if peculiar infrastructural developments are met in some areas like transport, rail roads, and electricity, thus, providing prerequisites for industrial take off. Indeed, the infrastructural development is essential and preconditions for industrial development particularly in the high labor manufacturing sectors in Africa.

Putting in place the monitoring and evaluation mechanisms as well as accountability is significant for industrial policy framework to function. Consequently, the industrial projects and policies in Africa should be reviewed on a periodic basis so as to ascertain the underperforming sectors in order to adjust policies and projects that suite local needs and conditions. Oyeyinka and Sampath in their article 'Institutional Capacity and Policy Choices for Latecomer Technology Development' (2012) observed that industrial technology requires policy choices that are supported by institutions within the state or its agencies. According to their article, it is only the government through its developmental initiatives that is able to create the necessary opportunities for innovative products, market and supply that can support small industries. Thus, the notion is predicated on the assumption that neoclassical models of free market system tend to adversely hurt states with poor or weak institutions due to the lack of perfect information system in the state. As a result, the government's intervention is to 'mimic the market mechanism by creating conditions that minimize the uncertainty, and socialize risk inherent to industrial activities and encourage entrepreneurship and local technological advancement' (Oyeyinka and Sampath 2012).

\section{CONCLUSION}

In conclusion, we can say that the state's role in promoting the technological development as basis for industrial development in latecomer countries cannot be down played in sub-Saharan African states, given the significant success stories chalked by East Asian countries structural transformations of their economies in the last four decades. Thus sub-Saharan African countries need not be afraid to pursue international trade, since the industrial policy would help to transform the structure of the mode of production so as to compete in the global market. 


\section{REFERENCES}

Altenburg, T. 2011. Industrial Policy in Developing Countries: Overview and Lessons from seven Country Cases. Discussion Paper 4/2011. Bonn: German Development Institute / Deutsches Institut für Entwicklungspolitik.

Norman, A., Botchewey, K., Stein, H. and Stiglitz, J. 2012. Good Growth and Governance in Africa: Rethinking Development Strategies. Oxford New York: Oxford University Press .

Norman, A., and Stiglitz, J. 2012. Strategies for African Development. In Kwesi Botchwey, Howard Stein, and Joseph Stiglitz Akbar Norman,Good Growth and Governance in Africa: Rethinking Development Strategies (pp. 3-47). Oxford New York : Oxoford University Press.

Ohno, I. and Ohno, K. 2012. Dynamic Capacity Development: What Africa Can Learn from Industrial Policy Formulation in East Asia. In Botchwey, K., Stein, H., Stiglitz, J., and Norman, A. (eds.), Good Growth and Governance in Africa: Rethinking Development Strategies (pp. 221-245). Oxford New York: Oxford University Press.

Oyeyinka, B. O., Sampath, P. G. 2012. Institutional Capacity and Policy Choices for Latecomer Technology Development. In Botchwey, K., Stein, H., Stiglitz, J., and Norman, A. (eds.), Good Growth and Governance in Africa (pp. 273-297). Oxford, UK: Oxford University Press.

Sen, K., and te Velde, W. 2012. State - Business Relations, Investment, Climate Reform and Economic Growth in Sub-Saharan Africa. In Botchwey, K., Stein, H., Stiglitz, J., and Norman, A. (eds.), Good Growth and Governace in Africa (pp. 303-321). Oxford: Oxford University Press.

Stein, H. 2012. Africa, Industrial Policy, and Export Processing Zones: Lessons from Asia. In Botchwey, K., Stein, H., Stiglitz, J., and Norman, A. (eds.), Good Growth and Governance in Africa: Rethinking Development Strategies (pp. 322-344). Oxford New York: Oxford University Press.

Watanabe, M., and Hanatani, A. 2012. Issues in Africa's Industrial Policy Process. In Botchwey K., Stein H., Stiglitz J., and Norman A. (eds.), Good Growth and Governance in Africa: Rethinking Development Strategies (pp. 372-405). Oxford New York: Oxford University Press.

Zalk, N. 2012. South African Post - Apartheid Policies towards Industrilization: Tentative Implications for other African Countries, Good Growth and Governance in Africa. In Botchwey, K., Stein, H., Stiglitz, J., and Norman, A. (eds.), Good Growth and Governace in Africa. Oxford: Oxford University Press.

Zenawi, M. 2012. States and Markets: Neoliberal Limitations and the Case for a Developmental State. In Botchwey, K., Stein, H., Stiglitz, J., and Norman, A. (eds.), Good Growth and Governance in Africa: Rethinking Development Strategies (pp. 140-174). Oxford New York: Oxford University Press. 